\title{
A further insight into the syntax-semantics of pluractionality*
}

\author{
Gianina Iordăchioaia \\ University of Stuttgart
}

\author{
Elena Soare \\ University of Paris 8
}

\begin{abstract}
In this paper we aim at a better understanding of the syntax-semantics of pluractional operators (POs) as markers of verbal plurality (Lasersohn 1995, Van Geenhoven 2004, Laca 2006). While previous literature argues or assumes that POs are (possibly lexical) plural operators that attach at the V level, we bring evidence in favor of a treatment of POs as Aspect level operators that bind plural event variables (as in Ferreira 2005). We formulate our claims on the basis of the Romanian supine, the nominal form of which has previously been argued to carry a PO (Iordăchioaia \& Soare 2008).
\end{abstract}

Keywords: syntax-semantics, pluractionality, distributivity, Romanian supine

\section{Introduction}

This paper focuses on the syntax-semantics interface of pluractional operators (henceforth, PO) from the perspective of a covert PO that has been shown to appear in the Romanian (deverbal) supine nominal (Iordăchioaia \& Soare 2008). Starting with the assumption that plural operators have direct correspondents in the nominal and the verbal domain (see Mourelatos 1978, Krifka 1989, Jackendoff 1991, among others), a closer examination of the properties of the supine offers us a deeper insight into the role of POs in language.

Pluractional operators have been described as "frequently reduplicative, most often derivational rather than inflectional" morphemes "that attach to the verb to indicate a multiplicity of actions, whether involving multiple participants, times, or locations" (Lasersohn 1995: 238, 240). Thus in the presence of such a marker, "the verb is understood to represent the occurrence of multiple events" (Lasersohn 1995: 238-241, see also Van Geenhoven 2004, Laca 2006, Wood 2007, Tovena \& Kihm 2008, and Cabredo Hofherr 2010 for an overview).

For the purposes of our paper it is important to distinguish between "event-

* We thank the editors of this volume, Artemis Alexiadou, Robert Henderson, and especially Christopher Piñòn for valuable comments and proofreading. Iordăchioaia's work has been supported by a DFG grant to the SFB 732 Incremental Specification in Context. 
internal" and "event-external" pluractionality (Wood 2007, based on Cusic 1981). The former notion is best illustrated in English by lexical verbs like nibble as opposed to bite, while the latter is usually contributed by adverbs that indicate a repeated event on a single occasion (e.g. 'to bite the cheese again and again'), or on several occasions (e.g. 'to always/often/usually bite the cheese'). We take the former type to be specified in the lexical semantics of the verb (see also Tovena \& Kihm 2008), and we consider the latter to involve compositional semantics above the lexicon. Our aim is to throw more light into the syntax-semantics of the second type of pluractionality. Since, we will see, the PO effect in the Romanian supine is obtained in the syntax, it cannot be the result of a lexical operation.

It has been customary in the semantic literature that analyzes pluractionality (in particular, Lasersohn 1995, Van Geenhoven 2004, Laca 2007) to consider the $\mathrm{PO}$ as a kind of $\mathrm{V}$ level operator that pluralizes the event of the verb. The effect of a PO is thus very similar to Link's (1983) star operator, to which the various special pluractional effects of each PO are added as, for instance, low or high variant frequency (Van Geenhoven 2004). These approaches, we will see, pose two independent problems: one that directly has to do with the PO in the Romanian supine which cannot be accommodated under such an analysis, and another one that has to do with language economy. First, the supine PO cannot be treated as a V level operator as this cannot account for the lack of PO effects in contexts where the morphological form of the verb is identical to that of the nominal supine. The PO effect in the Romanian supine is necessarily related to the nominal context in which this particular verbal form is used and its properties can only be explained if the PO is taken to be hosted by AspectP, the functional projection carrying grammatical aspect. Second, under the widespread assumption that lexical verbs (at least) in languages like English and Romanian are cumulative, i.e. start out with a plural event denotation (see Krifka 1992, Schein 1993, Landman 1996, Kratzer 2008), the use of POs in natural language to mark precisely event plurality at the $\mathrm{V}$ level seems superfluous.

Our present examination of the PO in the Romanian supine contributes to the latter issue by showing that, independently of whether POs are used to express plurality of events at the $\mathrm{V}$ level in, possibly, some language(s), there are also POs that act at the level of grammatical aspect. We make use of Ferreira's (2005) insight that natural languages have plural (nominal and verbal) operators and we will argue that the supine PO in Romanian is an aspectual operator that binds plural events. At the same time, we reconcile the insights of the above-mentioned $\mathrm{V}$ level analyses with our previous syntactic account in Iordăchioaia \& Soare (2008) where we argue that the supine PO is hosted by an aspectual functional projection and we thus pave the ground for a syntax-semantics interface of POs.

The rest of the paper is organized as follows. In Section 2, we introduce the Romanian supine, and present evidence for the pluractional semantics of the 
nominal form. Section 3 revisits previous analyses on pluractionality and their shortcomings with respect to the nominal supine. In Section 4 we investigate the properties of the PO in the nominal supine by comparison with nominal operators and bare habituals. We conclude that the PO must be an operator over plural events. We sketch a syntax-semantics interface for the nominal supine in Section 5 , and conclude in Section 6.

\section{Pluractionality in the Nominal Supine}

\subsection{Romanian supine: an overview}

The supine in Romanian is built on the past participial stem as in (1); one could consider it a special use of the past participle. ${ }^{1}$ Traditional grammars distinguish between a 'nominal supine' and a 'verbal supine', the function of the latter preserving some of the uses of the Latin supine. The nominal supine is an eventdenoting deverbal nominalization in which the masculine-neuter form of the (enclitic) definite determiner '-(u)l' is added to the past participial stem. ${ }^{2}$ It only combines with the definite determiner, while its arguments either carry genitive case or are bare plurals preceded by the preposition de 'of' (see (2a)). The verbal supine shows up in verbal periphrases, reduced relatives and 'tough'-constructions, it is bare, is usually preceded by prepositions (e.g. de 'of', la 'at'), and can take arguments marked with (weak) accusative case (see Soare 2002, and (2b)). In this paper we focus on the nominal supine and we will often employ the term 'supine' to refer to the nominal form in (2a).

\begin{tabular}{|c|c|c|c|}
\hline $\begin{array}{l}\text { Infinitive } \\
\text { a chema }\end{array}$ & $\begin{array}{l}\text { Past participle } \\
\text { chema-t }\end{array}$ & $\begin{array}{l}\text { Nominal supine } \\
\text { chema-t -ul }\end{array}$ & $\begin{array}{l}\text { Verbal supine } \\
\text { de/la chema-t }\end{array}$ \\
\hline to call & call -PastPrt & call -Sup-the & of/to call -Sup \\
\hline 'to call' & 'called' & 'the calling' & '(of) calling/to call' \\
\hline
\end{tabular}

(2) a. Culesul merelor/ de mere durează zile în şir harvest.Sup.the apples.the.Gen/of apples lasts days in row 'The harvesting of (the) apples lasts days in a row.'

b. Ion $\{\mathrm{s}-\mathrm{a}$ apucat de/a plecat la $\}$ cules merele. John Rf-has grabbed of/has left at harvest.Sup apples.the 'John started harvesting/went to harvest the apples.'

1 We use the gloss Sup for 'supine' for consistency with the label of the construction, but the morphology is actually identical to the past participle.

2 Note that this is different from what is called a past participial nominalization in Romanian which denotes an individual (not an event): e.g. nou venitul 'the newly arrived one'. 


\subsection{The pluractional operator}

Iordăchioaia \& Soare (2008) notice a contrast between infinitive and supine nominalizations in Romanian, to the extent that the former allow plural marking, while the latter do not, as illustrated in (3). They explain this difference by arguing that the nominal supine already denotes a plural (of events) which is incompatible with further (nominal) pluralization.

(3) demolă $-\mathbf{r}$-i -le/*demola $-\mathbf{t}$-uri-le frecvente ale cartierelor vechi demolish-Inf-Pl-the/demolish-Sup-Pl-the frequent-Pl of quarters.Gen old de către comunişti

by to communists

'the frequent demolitions of old quarters by the communists'

The first piece of evidence that the plural denotation of the nominal supine is contributed by a covert PO comes from the lack of multiplicity effects with singular indefinites, and the multiplicity effects with plurals which have also been observed in the behavior of POs in West Greenlandic and Spanish (Van Geenhoven 2004 and Laca 2006). The use of the singular indefinite un jurnalist 'a journalist' in (4) only has an interpretation in which there are several killing events whose patient is one and the same journalist.

(4) Ucisul de jurnalişti/*unui jurnalist de către mafia politică a

kill.Sup.the of journalists/a.Gen journalist by to mafia political has stârnit mass media.

stirred mass media

'The killing of journalists by the political mafia stirred the mass media.'

Second, the nominal supine is incompatible with idiomatic adverbials like 'in one gulp', 'in one breath', 'in one sweep' which preclude a subdivision of the running time of the event, although they are not punctual as their compatibility with accomplishments in (5a) indicates (Laca 2006). To show that the incompatibility does not lie in the nominal nature of the supine nominalization in $(5 b)$, note that the infinitival nominalization is grammatical in the same context.

(5) a. A citit romanul dintr-o răsuflare. has read novel.the in one breath 'He read the novel in one breath.'

b. citirea/ *cititul romanului dintr-o răsuflare read.Inf.the/read.Sup.the novel.the.Gen in one breath 'the reading of the novel in one breath' 
Third, the nominal supine triggers aspect shift (see de Swart 1998): it pluralizes achievements and makes them compatible with for-adverbials, which are known to only modify unbounded events (6a). Activities often require the bounding function until to be compatible with the plural triggered by the supine (6b). The logic behind this is that, like the nominal plural which can only be added to bounded entities (i.e. count nouns), the supine PO must combine with bounded/telic events (see Mourelatos 1978, Jackendoff 1991, Borer 2005: vol. I, Alexiadou, Iordăchioaia \& Soare 2010). Activities are unbounded, so they must be turned into bounded events by until to undergo pluralization in the supine. Both sentences in (6) receive a habitual interpretation which is a typical reading for the nominal supine, besides the generic one (see Soare 2006 for details).

a. Sositul lui Ion cu întârziere timp de 2 ani i -a arrive.Sup.the John.Gen with delay time of 2 years him-has adus concedierea.

brought firing

'John's (habit of) arriving late for two years brought about his being fired.'

b. Muncitul lui Ion *(până la miezul nopţii) o work.Sup.the John.Gen until at middle night.Gen her îngrijorează pe soţia lui. worries Acc wife his 'John's (habit of) working till midnight worries his wife.'

The evidence for aspect shift in (6), besides syntactic evidence from the compatibility with aspectual adverbs, leads Iordăchioaia \& Soare (2008) to conclude that the nominal supine must include a grammatical/outer aspect projection just like verbal constructions, with the difference that AspectP is now embedded under a DP, and not a TP. This claim is made from the perspective of a nominal-verbal parallelism a la Abney (1987) between AspectP and NumberP (see Alexiadou, Iordăchioaia \& Soare 2010 for details and other deverbal nominalizations that inherit AspectP from the original verb). They propose the structure in (7) for the nominal supine, where AspectP hosts the PO whose contribution is unboundedness/plurality.

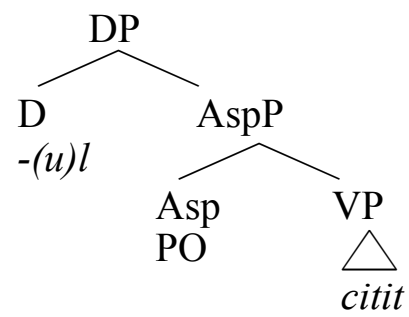




\section{Previous approaches to pluractionality and challenges}

Following Lasersohn's (1995) first formal semantic proposal, later accounts of POs in various languages assumed that these markers attach at the V level in the syntax. Lasersohn's analysis is motivated by the initial observation that POs are morphemes that are incorporated in the verb form. However, other instances of POs such as, for instance, the Spanish pluractionals andar 'walk'/ir 'go' + gerund addressed in Laca 2006 are periphrastic. Laca takes POs to attach at the V level in order to account for the different scope properties that POs and frequency adverbs like regularly or occasionally have. Unlike POs, the latter can take either wide or narrow scope with respect to singular indefinites as in (8), an effect that Laca explains in the syntax: for the wide scope reading, the adverb attaches at the VP level in (8a), and for the narrow scope reading, it attaches at the V level in (8b). The Romanian data in (4) and the West Greenlandic (9), where the use of the PO qattaar only allows a reading where the same bomb exploded several times, should consequently indicate that POs only take narrow scope with respect to indefinites, so they must attach at the $\mathrm{V}$ level, but we will argue against this idea.

(8) He occasionally met a sailor.

a. [occasionally [meet a sailor]]

b. [[occasionally meet] a sailor $]$

(9) ?Qaartartuq sivisuu-mik qaar -qattaar-puq

bomb.Abs lenghty.Ins explode-PO -Ind.[-tr].3sg

'A/the bomb exploded again and again for a long time.'

(Van Geenhoven 2004: 147)

Van Geenhoven's (2004) analysis is built on the same assumption, although she does not exclude the possibility that POs might also attach at a higher level. In addition, Van Geenhoven also argues that POs contribute atelicity, i.e. only act on the lexical aspect of the verb, which we will show is incompatible with the nominal supine in Romanian. ${ }^{3}$

There are two kinds of challenges for these accounts: one comes from the particular behavior of the nominal supine and one concerns the theoretical compatibility between V level POs and the lexical cumulativity of verbs as a (possible) semantic universal. We address both of them below.

3 We assume that (a)telicity is a matter of lexical aspect and is built within the VP, while (im)perfectivity expresses grammatical aspect and is hosted by AspectP. 


\subsection{The PO in the nominal supine is higher than $\mathrm{V}$}

To begin with, the PO in the nominal supine cannot successfully be accounted for if we assume that it attaches at the lexical level as in Lasersohn 1995. First, the PO has no morphological realization of its own (see the morphology of the nominal supine in (1)). Second, the two morphological components of the nominal supine are neither individually nor together responsible for the PO effects. In support of this claim, note that the two components of the nominal supine (the past participle and the definite determiner) may appear in other contexts without PO effects: the past participle in complex verbal forms is fine with singular indefinites (10a) and so is the verbal supine in $(10 \mathrm{~b})$, while the definite article can appear with infinitival eventive nominalizations without $\mathrm{PO}$ effects (see (10), (11) vs. (4)).

(10) a. Mafia politică a ucis un jurnalist. mafia political has killed a journalist 'The political mafia killed a journalist.'

b. Rămâne de găsit soluția. remains of find. Sup solution-the 'The solution remains to be found.'

(11) Uciderea unui jurnalist de către mafia politică a stârnit mass media. kill.Inf.the a.Gen journalist by to mafia political has stirred mass media 'The killing of a journalist by the political mafia stirred the mass media.'

In addition, Romanian has deverbal nouns like the ones in (12) which are made up of the past participle verbal form and the definite determiner, but they usually denote 'the entity that is $\mathrm{V}$-ed' (12c), or they acquire a lexicalized meaning (12a, b), so they are not eventive, and, importantly, they are not pluractional. This suggests that the morphological combination of a past participle and the definite determiner into a deverbal nominal does not necessarily trigger pluractionality either. Thus it must be some additional covert element in the make-up of the eventive nominal that contributes the PO. Below we argue that it is a grammatical aspect value that is realized in the syntax.

(12) a. avut-ul (have.PastPrt-the) 'the wealth'

b. venit-ul (come.PastPrt-the) 'the income'

c. urmărit-ul (follow.PastPrt-the) 'the followed one'

Laca (2006) analyzes the POs in Spanish verbal periphrases as attaching to V to account for the obligatory narrow scope of the PO with respect to singular indefinites as in (4). Given the comparison with frequency adverbials, it is 
obvious that she assumes the PO to be represented in the syntax, and not inserted by a lexical rule like in Lasersohn 1995. However, it is hard to imagine how such an analysis would cope with the aspectual properties of the nominal supine, in particular with the evidence that it contributes grammatical aspect. A V level analysis of the PO leads one to state that its aspectual contribution is atelicity, just like Van Geenhoven (2004) proposes for West Greenlandic. Under this account, however, the co-occurrence of in-PPs, which modify telic events, with for-PPs, which modify atelic events, in the nominal supine in (13) is left unexplained, as one expects the lexical aspect value to be either telic, or atelic, but not both.

(13) Traversatul râului în cinci minute timp de două luni cross.Sup.the river.the.Gen in five minutes time of two months (zi de zi) 1-a făcut pe Ion vedetă printre localnici. (day by day) him-has made Acc John star among locals 'John's (daily) crossing the river in five minutes over a period of two months made him a star among the locals.'

This behavior is in turn easy to account for if we assume that there is a grammatical aspect level (AspectP) in the nominal supine that hosts the PO, and that the in-PP modifies the inner (telic) aspect of the accomplishment verb, while the for-PP modifies the outer (unbounded) aspect of the supine, just like in a purely verbal context as the one in (14) (see Verkuyl 1993, Borer 2005: vol II).

(14) Ion a traversat râul în cinci minute (zi de zi) timp de două luni. John has crossed river.the in 5 minutes (day by day) time of two months 'John (daily) crossed the river in five minutes over a period of two months.'

\subsection{V level pluractionality and the lexical cumulativity of verbs}

Besides the problems specific to the nominal supine in Romanian, the V level analysis of POs also encounters a more theoretical challenge.

(15) below, adapted from Lasersohn 1995, is the simplest formulation of the semantic analysis of POs under the assumption that they attach to the verb. It says that the V-PO complex selects sets E of events e of which the predication of the verb holds, such that the cardinality of the selected set is greater than or equal to some contextually specified number $\mathrm{n}$.

$$
[[\mathrm{V}-\mathrm{PO}]]=\lambda \mathrm{E} . \forall \mathrm{e} \in \mathrm{E}[\mathrm{V}(\mathrm{e}) \&|\mathrm{E}| \geq \mathrm{n}]
$$

Various works like Krifka 1989, Schein 1993, Landman 1996, Kratzer 2008 provide compelling evidence that at least in languages like English, lexical verbs 
come with a plural denotation as in (16), where the $* \mathbf{V}$ is the closure of the set $\mathbf{V}$ under sum formation. This property generally explains the fact that sentences like (17) freely get a distributive reading (i.e. several events), besides the collective one (i.e. one event): the verb is ambiguous between a singular event and a plural event which can be distributed over the plural individuals. For theories that take the distributive reading in (14) to come exclusively from the plural DPs, examples like (18) taken from Kratzer 2008 cannot be explained: (18) says that one single phone number was dialed several times, and this can only be obtained if the verb itself has a plural denotation.

(16) $[[\mathrm{V}]]=* \mathbf{V}$

(17) a. John, Mary and Paul lifted the chair. b. John lifted three chairs.

(18) I dialed a wrong phone number for five minutes.

The Romanian sentences in (19) exhibit the same readings as the English ones, so lexical cumulativity also characterizes Romanian verbs.

(19) a. Ion, Maria şi Paul au ridicat scaunul.

John, Mary and Paul have lifted chair.the

b. Ion a ridicat trei scaune.

John has lifted three chairs

c. Am format un număr greşit timp de cinci minute.

have dialed a number wrong time of five minutes

If verbs are lexically cumulative in (at least) some languages, the use of POs in those languages is unexpected, or at least poses questions as to why language economy should allow this redundancy at the cost of an additional operator. ${ }^{4}$ What we expect is either that a language employs POs because its verbs are lexically singular, or that the PO contributes more information than a simple plural in a language with lexically cumulative verbs. ${ }^{5}$

To bring some light into this general issue and to find out what contribution the supine PO has in Romanian, in the next section we compare its behavior with

4 Müller \& Sanchez-Mendes (2008) describe such a situation for Karitiana POs where they argue that verbs are lexically cumulative and POs disambiguate them for a plural-only interpretation. Their prediction is that the PO in this language simply reduces the number of possible readings of a verb and thus triggers ungrammaticality in a context that would be grammatical in its absence. 5 The supine PO in Romanian has no additional information like FREQ or INCR in Spanish (Laca 2006) or West Greenlandic (Van Geenhoven 2004). 
that of pluralities of individuals in the nominal domain. The aim is to identify what kind of nominal plural the PO in the supine resembles.

\section{The PO in the supine and nominal operators}

The candidate in the nominal domain which the PO could most likely resemble is the bare plural. The V level approaches to POs already make this prediction, if we stay within a simple analysis of plural marking as an operator on the nominal head N. ${ }^{6}$ To test this hypothesis, we investigate the interaction of the supine PO with what Farkas $(1997,2002)$ calls 'dependent indefinites', but we will refer to them as 'câte indefinites' to avoid any commitment to her analysis. We will see that the nominal supine differs from bare plurals in being able to license such indefinites.

\subsection{The supine and câte indefinites}

Câte indefinites are distributive operators that must co-occur with a form of plural individuals or events with respect to which they distribute. Farkas $(1997,2002)$ formulates this as a condition on the variable introduced by câte to co-vary with another individual or situational variable provided by the context. Without making any commitment to a particular analysis of such indefinites, we will loosely call the expressions in whose context câte can occur its (possible) licensers and we will investigate what properties they have in common.

(20) summarizes the nominal licensers for câte: definite plurals, quantifiers with plural nouns, and every are fine, but singular indefinite or definite nouns are not. $^{7}$ According to Farkas, universal every licenses câte because the variable it binds gets at least two variable assignments, so it counts as plural.

(20) Studenţii/ mulți/doi/nişte studenţi/fiecare/*un student/*studentul students.the/many/two/some students/every/ a student/student.the $\mathrm{au} / \mathrm{a} \quad$ citit câte o carte.

have/has read CI a book

'The students/many/two/some students/every student/*a student/*the student read a book each.'

Importantly for our discussion, bare plurals are not able to license câte, although they technically may denote plural individuals, even if they also denote singular ones in contexts where they are number neutral. The data in (21) leads us

6 Even in frameworks that associate a very rich syntactic structure to the DP, as for instance Borer 2005: vol. I, the plural appears right above N. In a reduced syntactic structure like the one assumed in semantic approaches to POs this corresponds to $\mathrm{N}$ level attachment.

7 We translate câte with adnominal each without commiting to a parallelism between the two. 
Syntax-semantics of pluractionality

to conclude that the licenser of câte not only needs a plural denotation, but it must also carry an operator that binds the plural variable.

(21) Ion a dat (toate) florile/ *flori câte unei fete. John has given (all) flowers.the/flowers CI a.Dat girl.Dat 'John gave (all) the flowers/*flowers to a girl each.'

Unlike bare plurals, the supine in (22) is compatible with câte indefinites, which indicates that the supine cannot be a simple bare plural of events. Note that unlike in (4) above, the indefinite now takes narrow scope with respect to the supine PO. Similarly, (4) becomes grammatical if the singular indefinite contains câte, as illustrated in (23).

(22) Sositul câte unui student târziu a enervat-o pe profesoară. arrive.Sup.the CI a.Gen student late has irritated-her Acc teacher 'The late arrival of a student (now and then) irritated the teacher.'

(23) ucisul *(câte) unui jurnalist de către mafia politică kill.Sup.the (CI) a.Gen journalist by to mafia political 'the killing of a journalist now and then by the political mafia'

From this and the data in (20)-(21), we can only conclude that the PO in the nominal supine must contain an operator besides the plural. The supine being now known to carry grammatical aspect (Section 3.1), we consider the PO an aspectual operator. As further confirmation that the supine PO does not only disambiguate the verb for a plural-only denotation, note that the lexical cumulativity of verbs is not enough to license câte either (cf. $(19 \mathrm{c})):^{8}$

(24) Am format (*câte) un număr greşit timp de cinci minute. have dialed (CI) a number wrong time of five minutes 'I dialed a wrong phone number for five minutes.'

To understand the nature of the aspectual operator the supine PO involves, we now turn to a comparison with the covert habitual operator, which exhibits a striking resemblance to the supine.

8 To make câte possible in (21) we need a quantificational adverb like mereu 'always', or the adverb tot 'adverbial all' which we think is also a pluractional operator in Romanian. 


\subsection{The supine and bare habituals}

It is well known that present tense allows a habitual reading in many languages, although no overt habitual operator is present. In Romanian, (25) is ambiguous between an episodic and a habitual reading.

(25) Ion scrie poezii.

John writes poems

i. HAB: John writes poems.

ii. John is writing poems.

As noticed in Krifka et al. 1995, Rimell 2004, Cabredo Hofherr to appear and others, a habitual reading is excluded with a singular indefinite. The same holds of (26a) in Romanian, which in the habitual reading means that the same poem is written several times. This reminds us of the data in (4) with the supine. Similarly, a câte (singular) indefinite makes the habitual reading available, just like in the case of the supine in (23): the singular indefinite now varies with respect to the different occasions provided by the habitual.

(26) What does John do at work?

a. Ion scrie o poezie.

John writes a poem

i. \#HAB

ii. John is writing a poem.

b. Ion scrie câte o poezie.

John writes CI a poem

i. HAB: John writes a poem now and then.

ii. \#John is writing a poem.

We do not take this evidence to indicate that the supine PO and the bare habitual are one and the same operator, especially since the latter is far from being well understood, while the former is not always interpreted habitually. What the two must have in common, we think, is the type of operator that they express. Just like frequency adverbials, for instance, form a type of aspectual adverbs although they are different from one another (cf. occasionally, regularly, repeatedly etc.), we take the supine PO and the habitual to be aspectual operators over plural events, as in Ferreira 2005.

\subsection{Operators over plural variables}

Ferreira (2005) argues that the covert operator involved in bare habituals must be 
Syntax-semantics of pluractionality

a (verbal) THE (similar to the nominal definite article) that binds plural events. Although we take no stand on whether this is the right analysis for habituals, we make use of his insight that there are plural operators both in the nominal and the verbal domain and argue that the PO in the Romanian supine is such an operator.

Ferreira compares the scope interaction of nominal operators with singular indefinites and concludes that every and no in (27a) bind singular variables, whereas plural the and some in (27b) bind plural variables. In binding singular variables, every and no allow a singular individual (mother) to be related to another singular individual provided by the singular indefinite (one-year old child) in a way that is pragmatically felicitous in (27a). The infelicity of (27b) arises from the fact that by binding plural variables, the and some only associate plural individuals (mothers) to the singular individual introduced by the singular indefinite (one-year old child), which is pragmatically odd.

(27) a. Every/No mother of a one-year old child agreed to sign this form.

b. \#The/Some mothers of a one-year old child agreed to sign the form.

The restrictors of the two kinds of quantifiers are represented in (28) and (29): while the restrictor of the singular operators in (27a) selects singular mothers $\mathrm{x}$ for a singular child y in (28), the restrictor of the plural operators in (27b) selects sums X of mothers that are mapped onto a singular child y in (29). The latter leads to pragmatic anomaly. ${ }^{9}$

(28) $[[$ SG mother of a one-year old child $]]=\lambda x . \exists y[\operatorname{child}(y) \& \operatorname{mother}(x, y)]$

(29) $[[$ PL mother of a one-year old child $]]=\lambda X . \exists y[\operatorname{child}(y) \& \operatorname{mother}(X, y)]$

Further on, Ferreira observes that introducing a relative clause with plural operators makes the mapping of singular mothers onto singular children possible in (27b) and (29). This is illustrated in (30). To explain (30), he argues that the syntactic movement involved in relative clauses introduces a distributive operator that distributes the plural variable bound by the plural operator, thus allowing for the pragmatically felicitous reading (see Ferreira 2005: 106).

(30) The/some mothers [who have a one-year old child] agreed to sign this form.

More importantly for our discussion, Ferreira argues that in the verbal domain we have correspondents of the singular and plural operators in (27). He illustrates this parallelism with the adverb always and the bare habitual:

9 Capital letters are used from now on as variables over sums of individuals/events, as defined in Link 1983 and not for sets as in (15), which follows Lasersohn 1995. 
(31) a. John always writes a romantic song [at the pub $]_{\text {Foc. }}$

b. \#John writes a romantic song [at the pub] $]_{\text {Foc. }} \quad$ (habitual)

The corresponding representations are in (32) and (33) with the focused expression occupying the nuclear scope of the quantifier. As an operator over singular event variables, always maps a singular event of writing onto one romantic song. The habitual operator being identical to a verbal plural THE which binds plural events as Ferreira assumes, (33), the logical representation of habitual (31b), suggests that a single song $\mathrm{y}$ is written within a plural event $\mathrm{E}$. The pragmatic oddness thus rules out this interpretation for $(31 \mathrm{~b}){ }^{10}$

$$
\begin{aligned}
& \text { (32) } \forall_{\mathrm{e}}[\lambda \mathrm{e} . \exists \mathrm{y}(\operatorname{song}(\mathrm{y}) \& \text { write }(\mathrm{e}, \mathrm{j}, \mathrm{y}))][\lambda \mathrm{e} . \text { at_the_pub(e) }] \\
& \text { (33) } \mathrm{THE}_{\mathrm{E}}[\lambda \mathrm{E} . \exists \mathrm{y}(\operatorname{song}(\mathrm{y}) \& \operatorname{write}(\mathrm{E}, \mathrm{j}, \mathrm{y}))][\lambda \mathrm{E} \text {. at_the_pub(E)] }
\end{aligned}
$$

Like in the case of the nominal quantifiers in (30), the addition of an adverbial clause makes a sentence like (31b) allow a habitual interpretation as in (34a). This grammaticality change receives the same explanation as (31): the movement of the adverb within the relative clause introduces distributivity over atomic parts of the plural event $\mathrm{E}$. The result is the interpretation in (34b) where for each singular writing event $\mathrm{e}$ that is part of the plural event $\mathrm{E}$ there is one song that is written. ${ }^{11}$

(34) a. When John writes a romantic song, he goes to the pub.

b. $\quad \mathrm{THE}_{\mathrm{E}}[\lambda \mathrm{E} . \forall \mathrm{e} \leq \mathrm{E}(\exists \mathrm{y}(\operatorname{song}(\mathrm{y}) \&$ write $(\mathrm{e}, \mathrm{j}, \mathrm{y})))]$

$$
\left.\left[\lambda E . \exists E^{\prime}\left(\text { go_to_the_pub( } E^{\prime}\right) \& \Theta\left(E, E^{\prime}\right)\right)\right]
$$

From the perspective of these facts, we can now explain the similarity between the supine PO and the bare habitual as a consequence of their both being operators over plural events. The effect of the PO in (35) - which repeats the singular indefinite version of the nominal supine in (4) and (23) - is that the plural killing event $\mathrm{E}$ is mapped onto a single journalist y (cf. (33)). The distributive operator brought in by the câte indefinite allows the atomic parts of the plural event to be distributed over various single journalists as in (36), which is in this respect similar to (34b). The representations (35) and (36) are only tentative for now and stand for the sets of plural events that are part of the denotation of the two nominal constructions in the supine.

10 The two expressions within square brackets in (32) and (33) represent the restrictor and the nuclear scope of the operator.

11 The predicate $\Theta$ is taken in Ferreira 2005 to stand for a contextually determined relation between events for which he sends the reader to Rothstein 1995. 
Syntax-semantics of pluractionality

(35) *ucisul unui jurnalist de către mafia 'the killing of a journalist by the mafia' $[\lambda \mathrm{E} . \exists y($ journalist $(\mathrm{y}) \& \operatorname{kill}(\mathrm{E}, \mathrm{m}, \mathrm{y}))]$

(36) ucisul câte unui journalist de către mafia 'the killing of a journalist now and then by the mafia' $[\lambda \mathrm{E} . \forall \mathrm{e}: \mathrm{e}<\mathrm{E}(\exists \mathrm{y}$ journalist $(\mathrm{y}) \&$ kill $(\mathrm{e}, \mathrm{m}, \mathrm{y}))]$

\section{The syntax-semantics of the nominal supine}

In this section we sketch the syntactic and semantic components of the nominal supine including the PO in Romanian. We will not go into details concerning whether the PO has a tripartite structure like the bare habituals with a focused constituent that Ferreira discusses, and we do not follow his analysis beyond the straightforward claim that there are operators that bind plural variables among which we also include the Romanian PO.

We are rather interested in obtaining the right effects with the singular indefinites and with câte for the nominal supine, so we will follow a semantic analysis in the spirit of Lasersohn 1995, Van Geenhoven 2004 and Laca 2006 with a slightly modified syntax that can account for the grammatical aspect effects in Section 3.1 and the licensing conditions of câte indefinites described in Section 4.1. Given that we are dealing with a nominal construction that involves the definite determiner, we assume that the whole of it denotes a definite description of plural events, so it involves an iota operator over properties of plural events. We follow the syntactic structure given in Iordăchioaia \& Soare 2008: (37a) represents (35) and (37b) stands for (36), where we take distributive câte to be an operator that attaches to the DP it precedes.

(37) a

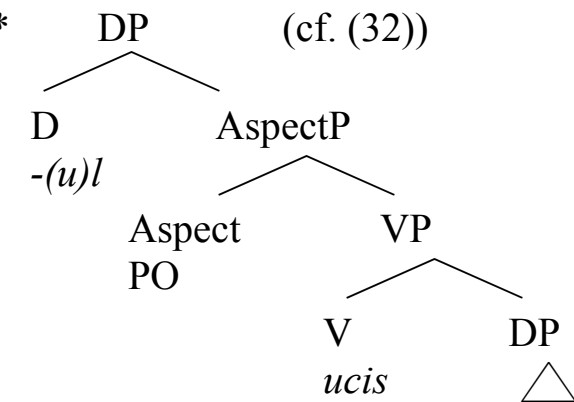

unui jurnalist 
b.

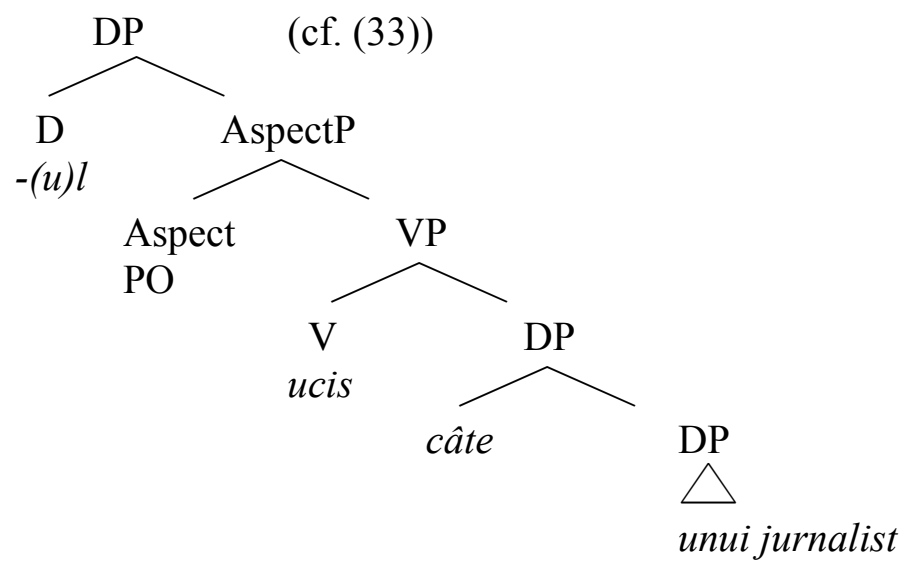

(38) a. $\quad[[\mathrm{ucis}]]=\lambda \mathrm{x}_{\mathrm{e}} \lambda \mathrm{E}_{\mathrm{s}} \cdot{ }^{*} \operatorname{kill}(\mathrm{x})(\mathrm{E})$

b. $\quad\left[[\right.$ unui jurnalist $]=\lambda \mathrm{P}_{\mathrm{e}(\mathrm{st})} \lambda \mathrm{E}_{\mathrm{s}}^{\prime} . \exists \mathrm{y}$ [journalist $\left.(\mathrm{y}) \& \mathrm{P}(\mathrm{y})\left(\mathrm{E}^{\prime}\right)\right]$

c. $\quad[[\mathrm{PO}]]=\lambda \mathrm{V}_{\mathrm{st}} \lambda \mathrm{E}_{\mathrm{s}}$. $\mathrm{V}\left(\mathrm{E}^{\prime \prime}\right) \& \operatorname{card}\left(\mathrm{E}^{\prime \prime}\right)>1$

d. $\quad[[\mathrm{ul}]]=\lambda \mathrm{V}_{\mathrm{st} .} \mathrm{l}(\mathrm{V})$

In what follows, we compositionally describe the semantic components in the trees in (37). As we discussed in Section 3.2, we take Romanian verbs to be lexically cumulative, so the node $\mathrm{V}$ in both trees has the denotation in (38a). We take only the theme to be part of the VP as in Kratzer 2003, and we leave the external argument and VoiceP out for the sake of simplicity. We take the DP unui jurnalist to be a generalized quantifier as in (38b), while the null PO is a modifier of properties of plural events as in (38c). It eventually enforces the verb it selects to predicate of only sums of more than one event. To avoid confusion with the cardinality of a set as in (15), we use the function $\operatorname{card}(X)$ to return the number of elements that are part of a sum X. The semantics for the PO is not much different from the one Lasersohn (1995) gives, except for the syntactic level where it attaches. Constraints like the lack of overlap between events given in Van Geenhoven 2004 and Laca 2006 can easily be mapped onto the PO, but we leave them aside as we have not discussed to what extent they hold for the supine. The definite determiner receives the usual denotation as an iota operator with type flexibility: in the nominal supine it takes properties of plural events and returns the largest such event (i.e. sum of events). Given the denotations in (38), we can derive the intermediate levels of the tree in (37a) as follows:

$$
\begin{aligned}
& \text { a. } \quad[[\mathrm{VP}]]=[[\text { ucis unui jurnalist }]]=[[\text { unui jurnalist }]]([[\mathrm{ucis}]]) \\
& \left.=\left[\lambda \mathrm{P}_{\mathrm{e}(\mathrm{st})} \lambda \mathrm{E}_{\mathrm{s} .}^{\prime} . \exists \mathrm{y} \text { [journalist }(\mathrm{y}) \& \mathrm{P}(\mathrm{y})\left(\mathrm{E}^{\prime}\right)\right]\right]\left(\lambda \mathrm{x}_{\mathrm{e}} \lambda \mathrm{E}_{\mathrm{s}} .{ }^{*} \mathbf{k i l l}(\mathrm{x})(\mathrm{E})\right) \\
& =\lambda \mathrm{E}_{\mathrm{s}}^{\prime} . \exists \mathrm{y}\left[\mathbf{j o u r n a l i s t}(\mathrm{y}) \&\left[\lambda \mathrm{x}_{\mathrm{e}} \lambda \mathrm{E}_{\mathrm{s}} . * \operatorname{kill}(\mathrm{x})(\mathrm{E})\right](\mathrm{y})\left(\mathrm{E}^{\prime}\right)\right] \\
& =\lambda \mathrm{E}_{\mathrm{s}}^{\prime} . \exists \mathrm{y}\left[\mathbf{j o u r n a l i s t}(\mathrm{y}) \& * \operatorname{kill}(\mathrm{y})\left(\mathrm{E}^{\prime}\right)\right]
\end{aligned}
$$


b. $\quad[[$ AspectP $]]=[[\mathrm{PO}$ ucis unui jurnalist $]]$

$=[[\mathrm{PO}]]([[$ ucis unui jurnalist $]])$

$=\left[\lambda \mathrm{V}_{\mathrm{st}} \lambda \mathrm{E}_{\mathrm{s}} . \mathrm{V}\left(\mathrm{E}^{\prime \prime}\right) \& \operatorname{card}\left(\mathrm{E}^{\prime \prime}\right)>1\right]$

$\left(\lambda \mathrm{E}_{\mathrm{s} .}^{\prime} . \exists \mathrm{y}\left[\right.\right.$ journalist $(\mathrm{y}) \& *^{*}$ kill $\left.\left.(\mathrm{y})\left(\mathrm{E}^{\prime}\right)\right]\right)$

$=\lambda \mathrm{E}_{\mathrm{s}} \cdot\left(\lambda \mathrm{E}_{\mathrm{s}}^{\prime} \cdot \exists \mathrm{y}\left[\mathbf{j o u r n a l i s t}(\mathrm{y}) \& *^{*} \operatorname{kill}(\mathrm{y})\left(\mathrm{E}^{\prime}\right)\right]\right)\left(\mathrm{E}^{\prime \prime}\right) \& \operatorname{card}\left(\mathrm{E}^{\prime \prime}\right)>1$

$=\lambda \mathrm{E}_{\mathrm{s}} . \exists \mathrm{y}\left[\right.$ journalist $\left.(\mathrm{y}) \& *^{*} \operatorname{kill}(\mathrm{y})\left(\mathrm{E}^{\prime \prime}\right)\right] \& \operatorname{card}\left(\mathrm{E}^{\prime \prime}\right)>1$

c. $\quad[[\mathrm{DP}]]=[[\mathrm{ucisul}$ unui jurnalist $]]=[[\mathrm{ul}]]([[\mathrm{PO}$ ucis unui jurnalist $]])$

$=\left[\lambda \mathrm{V}_{\mathrm{st} .} . \mathrm{V}(\mathrm{V})\right]\left(\lambda \mathrm{E}_{\mathrm{s} .} . \exists \mathrm{y}\left[\mathbf{j o u r n a l i s t}(\mathrm{y}) \& * \operatorname{kill}(\mathrm{y})\left(\mathrm{E}^{\prime \prime}\right)\right] \& \operatorname{card}\left(\mathrm{E}^{\prime \prime}\right)>1\right)$

$=\imath\left(\lambda \mathrm{E}_{\mathrm{s} .} . \exists \mathrm{y}[\right.$ journalist $\left.(\mathrm{y}) \& * \operatorname{kill}(\mathrm{y})(\mathrm{E} ")] \& \operatorname{card}\left(\mathrm{E}^{\prime \prime}\right)>1\right)$

According to (39c), the DP node in (37a) denotes the largest plural event in which a single journalist is killed. This gives the pragmatically odd interpretation in (35). To derive (36), with the distributive operator, we associate câte with the denotation in (40): it selects for a generalized quantifier, then a verb still missing its theme, and eventually, an event modifier, the PO itself, which introduces the plurality requirement on the event variable. ${ }^{12}$ If we introduce câte at the DP level, we obtain (41) for the complex nodes in (37b). (41d) stands for the plural event such that in each atomic sub-event a (different) journalist was killed.

$$
[[\text { câte }]]=\lambda \mathrm{Z}_{(\mathrm{e}(\mathrm{st}))(\mathrm{st})} \lambda \mathrm{V}_{\mathrm{e}(\mathrm{st})} \lambda \mathrm{Q}_{(\mathrm{st})(\mathrm{st})} \cdot \mathrm{Q}\left(\lambda \mathrm{F}_{\mathrm{s} .} \cdot \forall \mathrm{e}:(\mathrm{e}<\mathrm{F} \& \text { atom(e) }) \rightarrow \mathrm{Z}(\mathrm{V})(\mathrm{e})\right)
$$

(41) a. $\quad[[$ câte unui jurnalist $]]=[[$ câte $]]([[$ unui jurnalist $]])$

$$
\begin{array}{r}
=\left[\lambda \mathrm{Z}_{(\mathrm{e}(\mathrm{st}))(\mathrm{st})} \lambda \mathrm{V}_{\mathrm{e}(\mathrm{st})} \lambda \mathrm{Q}_{(\mathrm{st})(\mathrm{st}) \cdot} \mathrm{Q}\left(\lambda \mathrm{F}_{\mathrm{s}} \cdot \forall \mathrm{e}:(\mathrm{e}<\mathrm{F} \& \operatorname{atom}(\mathrm{e})) \rightarrow \mathrm{Z}(\mathrm{V})(\mathrm{e})\right)\right] \\
\left(\lambda \mathrm{P}_{\mathrm{e}(\mathrm{st})} \lambda \mathrm{E}_{\mathrm{s}}^{\prime} \cdot \exists \mathrm{y}\left[\text { journalist }(\mathrm{y}) \& \mathrm{P}(\mathrm{y})\left(\mathrm{E}^{\prime}\right)\right]\right) \\
=\lambda \mathrm{V}_{\mathrm{e}(\mathrm{st})} \lambda \mathrm{Q}_{(\mathrm{st})(\mathrm{st})} \cdot \mathrm{Q}\left[\lambda \mathrm{F}_{\mathrm{s}} \cdot \forall \mathrm{e}:(\mathrm{e}<\mathrm{F} \& \operatorname{atom}(\mathrm{e})) \rightarrow\right.
\end{array}
$$

$\exists y[j o u r n a l i s t(y) \& V(y)(e)]]$

b. $\quad[[$ ucis câte unui jurnalist $]]=[[$ câte unui jurnalist $]]([[$ ucis $]])$

$=\left[\lambda \mathrm{V}_{\mathrm{e}(\mathrm{st})} \lambda \mathrm{Q}_{(\mathrm{st})(\mathrm{st})} \cdot \mathrm{Q}\left(\lambda \mathrm{F}_{\mathrm{s}} \cdot \forall \mathrm{e}:(\mathrm{e}<\mathrm{F} \& \operatorname{atom}(\mathrm{e})) \rightarrow\right.\right.$

$\exists y$ [journalist(y) \& V(y)(e)])] $\left(\lambda \mathrm{x}_{\mathrm{e}} \lambda \mathrm{E}_{\mathrm{s}} \cdot{ }^{*}\right.$ kill(x)(E))

$=\lambda \mathrm{Q}_{(\mathrm{st})(\mathrm{st})} \cdot \mathrm{Q}\left(\lambda \mathrm{F}_{\mathrm{s}} \cdot \forall \mathrm{e}:(\mathrm{e}<\mathrm{F} \& \operatorname{atom}(\mathrm{e}))\right.$

$\rightarrow \exists y$ [journalist(y) \& *kill(y)(e)])

c. $\quad[[\mathrm{PO}$ ucis câte unui jurnalist $]]=[[$ ucis câte unui jurnalist $]]([[\mathrm{PO}]])$

$=\left[\lambda \mathrm{Q}_{(\mathrm{st})(\mathrm{st})} \cdot \mathrm{Q}\left(\lambda \mathrm{F}_{\mathrm{s}} \cdot \forall \mathrm{e}:(\mathrm{e}<\mathrm{F} \& \operatorname{atom}(\mathrm{e})) . \exists \mathrm{y}[\right.\right.$ journalist $(\mathrm{y})$

$$
\& * \operatorname{kill}(\mathrm{y})(\mathrm{e})])]\left(\lambda \mathrm{V}_{\mathrm{st}} \lambda \mathrm{E}_{\mathrm{s} .} \text {. V(E") \& } \operatorname{card}\left(\mathrm{E}^{\prime \prime}\right)>1\right)
$$

$=\left[\lambda \mathrm{V}_{\mathrm{st}} \lambda \mathrm{E}_{\mathrm{s} .} \mathrm{V}\left(\mathrm{E}^{\prime \prime}\right) \& \operatorname{card}\left(\mathrm{E}^{\prime \prime}\right)>1\right]$

$\left(\lambda \mathrm{F}_{\mathrm{s}} . \forall \mathrm{e}:(\mathrm{e}<\mathrm{F} \&\right.$ atom(e) $) \rightarrow \exists \mathrm{y}[$ journalist $(\mathrm{y}) \& *$ kill(y)(e)]

12 To make sure that câte only attaches to DPs with numerals, one would have to assume that it selects for NumPs in the syntax, but we do not go into further details on this issue. Importantly for our analysis, the syntactic label is the same before and after câte attaches. For simplicity, we take it to be DP. 


$$
=\lambda \mathrm{E}_{\mathrm{s} .}, \forall \mathrm{e}:(\mathrm{e}<\mathrm{E} " \& \operatorname{atom}(\mathrm{e})) \rightarrow \exists \mathrm{y}[\mathbf{j o u r n a l i s t}(\mathrm{y}) \& * \operatorname{kill}(\mathrm{y})(\mathrm{e})]
$$

$\& \operatorname{card}\left(E^{\prime \prime}\right)>1$

d. $\quad[[$ ucisul câte unui jurnalist $]]=[[\mathrm{ul}]]([[\mathrm{PO}$ ucis câte unui jurnalist $]])$

$=\left[\lambda \mathrm{V}_{\mathrm{st}} \cdot \mathrm{l}(\mathrm{V})\right]\left(\lambda \mathrm{E}_{\mathrm{s}} . \forall \mathrm{e}:(\mathrm{e}<\mathrm{E} " \&\right.$ atom $(\mathrm{e})) \rightarrow \exists \mathrm{y}[$ journalist $(\mathrm{y})$ $\& * \operatorname{kill}(\mathrm{y})(\mathrm{e})] \& \operatorname{card}(\mathrm{E} ")>1)$

$$
\begin{array}{r}
=\imath\left(\lambda \mathrm{E}{ }_{\mathrm{s} .} \cdot \forall \mathrm{e}:(\mathrm{e}<\mathrm{E} " \& \text { atom }(\mathrm{e})) \rightarrow \exists \mathrm{y}[\text { journalist }(\mathrm{y}) \& \text { * } \operatorname{kill}(\mathrm{y})(\mathrm{e})]\right. \\
\left.\& \operatorname{card}\left(\mathrm{E}^{\prime \prime}\right)>1\right)
\end{array}
$$

\section{Conclusion and further questions}

We have argued in favor of the existence of pluractional operators that are best treated as affecting the grammatical aspect, and not the lexical aspect of a verb. The syntactic consequence is that such POs are hosted by AspectP, and are not V level modifiers as usually assumed in the literature. This analysis also brings light into the role of POs in languages where verbs are lexically cumulative.

Our case study involved the Romanian nominal supine. The next issue one needs to clarify is which semantic pieces in this construction are responsible for the pluractional semantics. A first comparison with the verbal supine leads to the idea that the definite determiner plays an important role, since its absence in the verbal supine correlates with the lack of pluractional effects: the supine in (42) may receive both a singular and a plural event denotation.

(42) S -a apucat de citit ziarul acum două minute/doi ani.

Rf -has grabbed of read.Sup newspaper.the now two minutes/two years 'He started reading the newspaper two minutes/two years ago.'

\section{References}

Abney, Steve. 1987. The English Noun Phrase in its Sentential Aspect. Ph.D. dissertation, MIT.

Alexiadou, Artemis, Gianina Iordăchioaia \& Elena Soare. 2010. Number/Aspect interactions in the syntax of nominalizations: a DM approach. Journal of Linguistics, 46(3), 537-574.

Borer, Hagit. 2005. Structuring Sense, vol. I-II. Oxford: Oxford University Press.

Cabredo Hofherr, Patricia. 2010. Verbal plurality and event plurality. Lecture notes at DGfS-CNRS Summer School on Linguistic Typology, Leipzig, August 15 - September 3.

Cabredo Hofherr, Patricia. To appear. Bare singulars and bare habituals. In Claire Beyssade, Fabio Del Prete \& Alda Mari (eds.), Genericity. Oxford University Press. 
Syntax-semantics of pluractionality

Cusic, David. 1981. Verbal Plurality and Aspect. Ph.D. dissertation, Stanford University.

Farkas, Donka. 1997. Dependent indefinites. In Francis Corblin, Danièle Godard \& Jean-Marie Marandin (eds.), Empirical Issues in Formal Syntax and Semantics, 243-267. Bern: Peter Lang Publishers.

Farkas, Donka. 2002. Extreme non-specificity in Romanian. In Claire Beyssade, Reineke Bok-Bennema, Frank Drijkoningen \& Paola Monachesi (eds.), Romance Languages and Linguistic Theory 2000, 127-151. Amsterdam: John Benjamins.

Ferreira, Marcelo. 2005. Bare habituals and plural definite descriptions. Sinn und Bedeutung (SuB) 9, 102-115.

Iordăchioaia, Gianina \& Soare, Elena. 2008. Two kinds of event plurals: Evidence from Romanian nominalizations. In Olivier Bonami \& Patricia Cabredo Hofherr (eds.), Empirical Issues in Syntax and Semantics 7, 193-216.

Jackendoff, Ray. 1991. Parts and boundaries. Cognition 41: 9-45.

Kratzer, Angelika. 2003. The event argument and the semantics of verbs. Ms. University of Massachusetts at Amherst.

Kratzer, Angelika. 2008. On the plurality of verbs. In Johannes Dölling, Tatjana Heyde-Zybatow \& Martin Schäfer (eds.), Event Structures in Linguistic Form and Interpretation, 269-300. Berlin: Mouton de Gruyter.

Krifka, Manfred. 1989. Nominalreferenz und Zeitkonstitution. Zur Semantik von Massentermen, Plural-termen und Aspektklassen. München: Fink.

Krifka, Manfred. 1992. Thematic relations as links between nominal reference and temporal constitution. In Ivan Sag \& Anna Szabolsci, Lexical Matters, 29-53. Stanford: CSLI.

Krifka, Manfred, Francis Jeffry Pelletier, Gregory N. Carlson, Alice terMeulen, Godehard Link \& Gennaro Chierchia, 1995. Genericity: An introduction. In Gregory N. Carlson, and Francis Jeffry Pelletier (eds.), The Generic Book, 1124. Chicago: University of Chicago Press.

Laca, Brenda. 2006. Indefinites, quantifiers and pluractionals: What scope effects tell us about event pluralities. In Liliane Tasmowski \& Svetlana Vogeleer (eds.), Non-definiteness and Plurality, 191-217. Amsterdam: John Benjamins.

Landman, Fred. 1996. Plurality. In Shalom Lappin (ed.), The Handbook of Contemporary Semantic Theory, 425-457. Oxford: Blackwell Publishers.

Lasersohn, Peter. 1995. Plurality, Conjunction and Events. Dordrecht: Kluwer.

Link, Godehard. 1983. The logical analysis of plurals and mass terms: A latticetheoretical approach. In Rainer Bäuerle, Cristoph Schwarze \& Arnim von Stechow (eds.), Meaning, Use and Interpretation of Language, 302-323. Berlin: De Gruyter.

Mourelatos, Alexander. 1978. Events, processes and states. Linguistics and Philosophy 2 (3), 415-434. 
Müller, Ana \& Luciana Sanchez-Mendes. 2008. Pluractionality in Karitiana. In Atle Grønn (ed.), Sinn und Bedeutung (SuB) 12, 442-454. Oslo: ILOS.

Rimell, Laura. 2004. Habitual sentences and generic quantification. West Coast Conference on Formal Linguistics (WCCFL) 23, 663-676.

Rothstein, Susan. 1995. Adverbial quantification over events. Natural Language Semantics 3(1), 1-31.

Schein, Barry. 1993. Plurals and Events. Cambridge, MA: MIT Press.

Soare, Elena. 2002. Le Supin Roumain et la Théorie des Catégories Mixtes, thèse de doctorat, Université de Paris 7.

Soare, Elena. 2006. Why smoking is a (bad) habit. Bucharest Working Papers in Linguistics 8.

de Swart, Henriëtte. 1998. Aspect shift and coercion. Natural Language and Linguistic Theory, 16(2): 347-385.

Tovena, Lucia. \& Alain Kihm. 2008. Nibbling is not many bitings in French and Italian. 34th Annual Meeting of the Berkeley Linguistic Society.

Van Geenhoven, Veerle. 2004. For-adverbials, frequentative aspect, and pluractionality. Natural Language Semantics 12(2), 135-190.

Verkuyl, J. Henk. 1993. A Theory of Aspectuality. The Interaction between Temporal and Atemporal Structure. Cambridge: Cambridge University Press.

Wood, Esther. 2007. The semantic typology of pluractionality. Ph. D. dissertation, University of California, Berkeley.

Gianina Iordăchioaia

University of Stuttgart

Institut für Linguistik: Anglistik

Keplerstr. 17

70174 Stuttgart, Germany

gianina@ifla.uni-stuttgart.de
Elena Soare

University of Paris 8

UMR Structures Formelles du Langage

2 rue de la Liberté, D 322

92526 Saint-Denis cedex, France

elena.soare@univ-paris8.fr 